DOI 10.37882/2223-2982.2020.06-2.25

\title{
ВОПРОСЫ ДЕМОГРАФИИ И ЗДРАВООХРАНЕНИЯ В ВОСПРИЯТИИ УЧАСТНИКОВ IV ВСЕМИРНОГО РУССКОГО НАРОДНОГО СОБОРА (1997 Г.)
}

\section{ISSUES OF DEMOGRAPHY AND HEALTH IN THE PERCEPTION OF THE PARTICIPANTS OF THE IV WORLD RUSSIAN NATIONAL COUNCIL (1997)}

\section{A. Rudakov}

Summary: This article discusses the reaction of participants in the IV World Russian People's Cathedral to the demographic crisis and health problems in Russia in the 1990s. XX century The recession in the Russian Federation, which began at the turn of the 80 s and 90 s, led to negative changes in the field of demography and the organization of health care in the mid-1990s. continued to negatively affect the deterioration of the health status of citizens and the increase in fertility. The article provides the opinion of Metropolitan Kirill (since 2009 the Patriarch of Moscow and All Russia) about the need to treat the health of the nation as the highest state priority. The position of the IV World Russian People's Council that health care in Russia cannot be provided on a "residual basis" is noted. It was emphasized at the council that the gene pool of the peoples of the Russian Federation cannot be "at the cost of any social experiments". The delegates of the forum called for the implementation of government measures aimed at ensuring the rights of citizens, enshrined in the recently adopted Constitution of the Russian Federation, in the field of healthcare and public health. They revealed the need for a federal health concept. The congress noted the importance of adopting a special state program for protecting health and prescribing its financing as a separate line from the country's budget. The findings reveal the relationship of ideas voiced at the World Russian People's Council in 1997 with later adopted provisions of the program documents of the Russian Orthodox Church on the health of individuals and people, and especially the "Fundamentals of the Russian Orthodox Church's Social Concept".

Keywords: Russian Orthodox church, World Russian People's Council, Demography, Health of nation.
1990 -е годы ознаменовались значительным ухудшением демографической ситуации в России. К 1997 году рождаемость сократилась в полтора раза, смертность выросла в 1,6 раз, уровень заболеваемости населения повысился в 2,3 раза. За период с 1992 по 1996 год абсолютная естественная убыль населения составила 4,2 миллиона человека. В 1997 году естественная убыль населения фиксировалось в 71 регионе РФ. Тенденция роста смертности на фоне падения рождаемости получила в демографии обозначение «русский крест» [9. С. 10] и

\author{
Рудаков Александр Борисович \\ Аспирант, Ярославский государственный \\ университет им. П.Г. Демидова \\ arudakov@indox.ru
}

Аннотация: В данной статье рассматривается реакция участников IV Всемирного русского народного собора на демографический кризис и проблемы здравоохранения в России 1990-х гг. XX в. Спад экономики в Российской Федерации, начавшийся на рубеже 80-х - 90-х гг., привел к негативным изменениям в сфере демографии и организации работы здравоохранения и в середине 1990-х гг. продолжил негативно влиять на ухудшение состояния здоровья граждан и рост рождаемости. В статье приводится мнение митрополита Кирилла (с 2009 г. Патриарх Московский и всея Руси) о необходимости относиться к здоровью нации как к высшему государственному приоритету. Отмечается позиция IV Всемирного русского народного собора о том, что здравоохранение в России не может обеспечиваться по «остаточному принципу». На соборе было подчеркнуто, что генофонд народов Российской Федерации не может быть «ценой никаких социальных экспериментов». Делегаты форума призвали к реализации государственных мер, направленных на обеспечение прав граждан, закрепленных в недавно принятой Конституции РФ, В сфере здравоохранения и охраны здоровья населения. Они раскрыли необходимость принятия федеральной концепции охраны здоровья. На съезде отмечалось важность принятия специальной государственной программы охраны здоровья и прописать ее финансирование отдельной строкой из бюджета страны. В выводах раскрывается взаимосвязь идей, прозвучавших на Всемирном русском народном соборе в 1997 г., с принятыми позднее положениями программных документов Русской Православной Церкви по вопросам здоровья личности и народа, и прежде всего «Основ социальной концепции РПЦ».

Ключевые слова: русская православная церковь, Всемирный русский народный собор, Демография, Здоровье нации.

стала вызывать закономерную тревогу общественности.

Для Всемирного русского народного собора (ВРНC), созданного по инициативе представителей Русской Православной Церкви и патриотически настроенных объединений российской интеллигенции в 1993 года с целью обсуждения наиболее острых проблем, стоящих перед государством и обществом, тема демографического кризиса и проблема здравоохранения также находилась в числе приоритетных. По деятельности государства и общества, государства и Русской Православной 
Церкви, а также ВРНС в целях сохранения национальных традиций, генофонда русского народа и всех народов и народностей, проживающих в Российской Федерации, посвящена обширная научная и научно-популярная литература [2; 3; 4; 6; 7], но работа IV Всемирного русского народного собора по вопросам здоровья нации осталась вне поля зрения исследователей.

Между тем именно актуальным вопросам развития демографии и здравоохранения был посвящен состоявшийся с 5 по 7 мая 1997 года в Даниловом монастыре (г. Москва) IV Всемирный русский народный собор. Вполне закономерно, что эта важнейшая тема, волновавшая все российское общество, на форуме прозвучала как «Здоровье нации».

Открывая дискуссию, глава Всемирного русского народного собора Патриарх Московский и всея Руси Алексий Второй обратил внимание на «плачевное демографическое состояние нашего народа» [1. Л. 2] и констатировал, что России разрушается система бесплатной медицинской помощи всем гражданам страны. В числе симптомов кризиса российского здравоохранения Патриарх назвал бедственное положение клиник и медицинских научных центров, плачевное состояние сельской медицины, растущую недоступность многих видов медицинской помощи для малоимущих людей [1. Л. 2-3]. По словам Патриарха Алексия Второго, здоровье личности и народа, здоровье физическое и духовное должны стать общей заботой церкви, государства и общества.

В развитие данной проблематики, заместитель главы ВРНС, Митрополит Смоленский и Калининградский Кирилл (с 2009 года - Патриарх Московский и всея Руси) подчеркнул, что в жизни первых христиан огромное значение имело служение исцеления, оказание помощи больному человеку. В современное же время Церковь «не может игнорировать или отворачиваться от того, что происходит в области физической, природной, каково состояние физического здоровья человека, социальной культурной среды, которая оказывает колоссальное воздействие на формирование человеческой личности, на самом существовании человека» [1. Л. 17-18].

По словам митрополита Кирилла, экономический спад привел к негативным изменениям в сфере демографии и продолжает влиять на ухудшение состояния здоровья граждан. Религиозный деятель призвал задуматься над «ценой реформ», которые проводились с РФ с 1992 года и подчеркнул, что «здоровье нации, генофонд народа не могут быть ценой никаких социальных экспериментов».

Отметив, что Церковь не занимается политикой и не ставит своей целью критику тех или иных политических сил, митрополит Кирилл призвал относиться к здоровью нации как к высшему государственному приоритету. При этом здравоохранение не может обеспечиваться по «остаточному принципу», за счет остатков средств от других программ. «Никогда нельзя экономить на том, что составляет здоровье нашего народа» [10. С. 72-73], - отметил религиозный деятель. Коснувшись обсуждаемого в тот момент в Государственной Думе проекта закона «О репродуктивных правах населения», митрополит Кирилл заявил, что подобный закон должен обеспечивать право семей на рождение детей в максимальную социальную помощь, поддерживающую материнство и детство, а не планирование семьи в сторону ее сокращения [10. C. 74].

Митрополит Кирилл отметил также, что между нравственностью и выживанием существует прямая связь, причем не только для нашей страны, но и для всего мира. По мнению религиозного деятеля, в условиях истощения ресурсов, появления потенциально опасных технологий и загрязнения окружающей среды, опора на нравственный фактор является единственной возможностью сохранить планету от разрушительных катаклизмов и обеспечить человечество всем необходимым при растущей численности населения земного шара.

В ходе дискуссии на форуме выступили известные ученые А.Г. Чучалин, А.Ф. Цыб, Г.В. Осипов, председатель Государственной Думы Российской Федерации Г.Н. Селезнев, вице-премьер правительства РФ по вопросам социальной политики О.Н. Сысуев, мэр Москвы Ю.Н. Лужков, председатель Комитета по охране здоровья Госдумы РФ Н.Ф. Герасименко [1. Л. 64].

Итогом соборной дискуссии стало «Слово к соотечественников о духовном и физическом здоровье нации», в котором были обобщены основные идеи выступавших на форуме [8].

В программном документе соборного форума, в подготовке которого вместе с представителями Русской Православной Церкви приняли участие деятели медицинской науки и практикующие врачи, социологи, демографы, представители государственных и общественных структур, констатировалось, что состояние здоровья граждан РФ следует определить как неудовлетворительное и соответствующее, согласно критерием международной медицинской статистики, положению в наиболее отсталых и неразвитых странах мира.

В документе отмечалось, что важнейшей причиной, вызвавшей подобное положение дело, является снижение государственных ассигнований на здравоохранение. Так, если в Советском Союзе в 1971 году затраты на здравоохранение составляли около пяти процентов ВВП, то в 1996 году эти цифры составили лишь 2,8 процента, то есть снизились почти в два раза. При этом уровень 
оплаты труда врачей либо невыплаты зарплат привели к тому, что врачи поставлены в ситуацию, при которой не могут исполнить своих этических обязательств, зафиксированных в клятве Гиппократа, своего долга перед обществом. Хроническое недофинансирование даже вдвое сократившегося, по сравнению с советскими временами, бюджета сферы здравоохранения привело к массовому взиманию платы за оказание медицинской помощи, в том числе и неотложным показаниям, то есть к практически повсеместному разрушению бесплатного здравоохранения [8].

Участники ВРНС призвали начать активный диалог общества и власти по вопросам здоровья народа, которые должны стать основным критерием проводимой государством политики, ее соответствия национальным интересам страны. В частности, политическому руководству страны было предложено выступать перед народом с ежегодным обращением, посвященным проблемам здоровья нации.

Собравшиеся на форме представители общественности и Русской Православной Церкви призвали к реализации государственных мер, направленных на обеспечение конституционных прав граждан в сфере здравоохранения и констатировали необходимость принятия федеральной концепции охраны здоровья, которая бы служила осуществлению прав граждан на социальное и физическое благополучие, увеличение продолжительности жизни, психическое здоровье, что соответствует стратегии Всемирной Организации здравоохранения. Согласно этому документу, каждому гражданину должны быть обеспечены равные возможности доступа к социальным гарантиям и медицинским услугам с целью их гармоничного духовного и физического развития.

При этом участники форума выразили надежду, что принятие федеральной концепции охраны здоровья станет стимулом для определения последствий тех или иных экономических реформ, даст возможность установить соответствии целей и средств их достижения. К числу важнейших задач государств участники ВРНС отнесли и меры недопущении депопуляции населения России путем усиления мер по снижению детской смертности, охране плода и новорожденного, предотвращению сокращению продолжительности жизни среди взрослых.

Показательно, что члены ВРНС выразили обеспокоенность состоянием здоровья российских соотечественников, проживающих за рубежом. В частности, было констатировано, что они зачастую подвергаются дискриминации в новых постсоветских государствах, в том числе и в вопросах оказания медицинской помощи.
Было предложено также уделить первоочередное внимания здоровья молодежи, подрастающего поколения, принять по этому вопросу специальную программу, которая финансировалась бы отдельной строкой из госбюджета. В заключение участники ВРНС предложили перечень мер из двадцати пунктов, в числе которых были конкретные меры, касавшиеся сложившейся на тот момент общественно-политической ситуации [8].

В частности, было предложено финансировать здравоохранение в размере не менее 5 процентов от ВВП, принять ряд актуальных законов в сфере здравоохранения, в том числе «Кодекс об охране здоровья», создать федеральную систему медико-психологической помощи жертвам тоталитарных сект.

Участники форума также высказали поддержку проведения Второго Всероссийского Пироговского съезда врачей для обсуждения вопросов физического и духовного здоровья нации.

Отметим также, что в момент проведения съезда активно шла подготовка положений «Основ социальной концепции Русской Православной Церкви», где идеи IV Всемирного русского народного собора нашли свое отражение в XI [5] главе этого документа, посвященного проблемам здоровья личности и народа. Так, в пункте 3 XI «Основ ...» подчеркивалось, что необходимость участия Церкви в выработке такого понимания вопросов охраны здоровья нации, при котором гражданин мог бы осуществить свое право на физическое, духовное и психическое здоровье при максимально возможной продолжительности жизни. В документе также высказывалось мысль о необходимости доступности медицинской помощи для всех граждан, в том числе социально незащищенных.

В пункте 4 XI главы «Основ ...» говорилось о необходимости активной поддержки социальных и научно-медицинских программ по защите материнства и детства, оказания помощи гражданам в вопросах достойного воспитания детей [5].

Вместе с тем можно обнаружить и определенные отличия между тезисами идеи IV Всемирного русского народного собора и текстом «Основ ...» в той части, где говорилось о причинах сокращения численности населения России. В отличие от соборного форума, где «русский крест» объяснялся последствиями рыночных реформ, в Основах социальной концепции причинами депопуляции и критического состояния здоровья народов России были названы «войны, революция, голод и массовые репрессии, последствия которых усугубил глубокий общественный кризис конца столетия» [5]. 


\section{ЛИТЕРАТУРА}

1. Архив Экспертного центра Всемирного Русского Народного Собора. Ф. 2. Оп. 2. Д. 1.

2. Веремчук В.А. 25 лет Всемирному Русскому Народному Собору: этапы развития организации. Вестник Экспертного центра ВРНС. М.: Издательская группа РА «КРЕАТИВ плюс», 2018. Вып.5. С.12-18.

3. Ганичев В.М. Россия, песня и душа. М., 2018.301 с.

4. Иерусалимский Ю.Ю., Рудаков А.Б. Роль Всемирного Русского Народного Собора в консолидации российского общества в 1990-х годах // Дом Романовых и Ярославский край: материалы конференции / под ред. Ю.Ю. Иерусалимского. Ярославль: Индиго, 2019, С. 437-445.

5. Основы социальной концепции Русской Православной Церкви. Раздел II. Церковь и нация. https://mospat.ru/ru/documents/social-concepts/xi/

6. Перевезенцев С.В. Традиционализм. Русский взгляд // Родная Ладога. http://rodnayaladoga.ru/index.php/mirovozzrenie/1410-traditsionalizm-russkijvzglyad

7. Перевезенцев С.В. Церковь и общество: несколько слов о национальной традиции // Газета Союза писателей России. https://rospisatel.ru/perevezenzew. $\mathrm{htm}$

8. Слово к соотечественникам о духовном и физическом здоровье нации // Православная газета (г. Екатеринбург). 1997. № 13 (71).

9. Халтурина Д.А., Коротаев А.В. Русский крест: факторы, механизмы и пути преодоления демографического кризиса в России. М., 2013. 128 с.

10. Через духовное обновление к национальному возрождению: Выступления Святейшего Патриарха Московского и Всея Руси Кирилла на Соборах и Соборных слушаниях Всемирного Русского Народного Собора с 1993 по 2012 годы и принятые на них итоговые документы. М., 2012. 235 с.

с Рудаков Александр Борисович (arudakov@indox.ru).

Журнал «Современная наука: актуальные проблемы теории и практики»

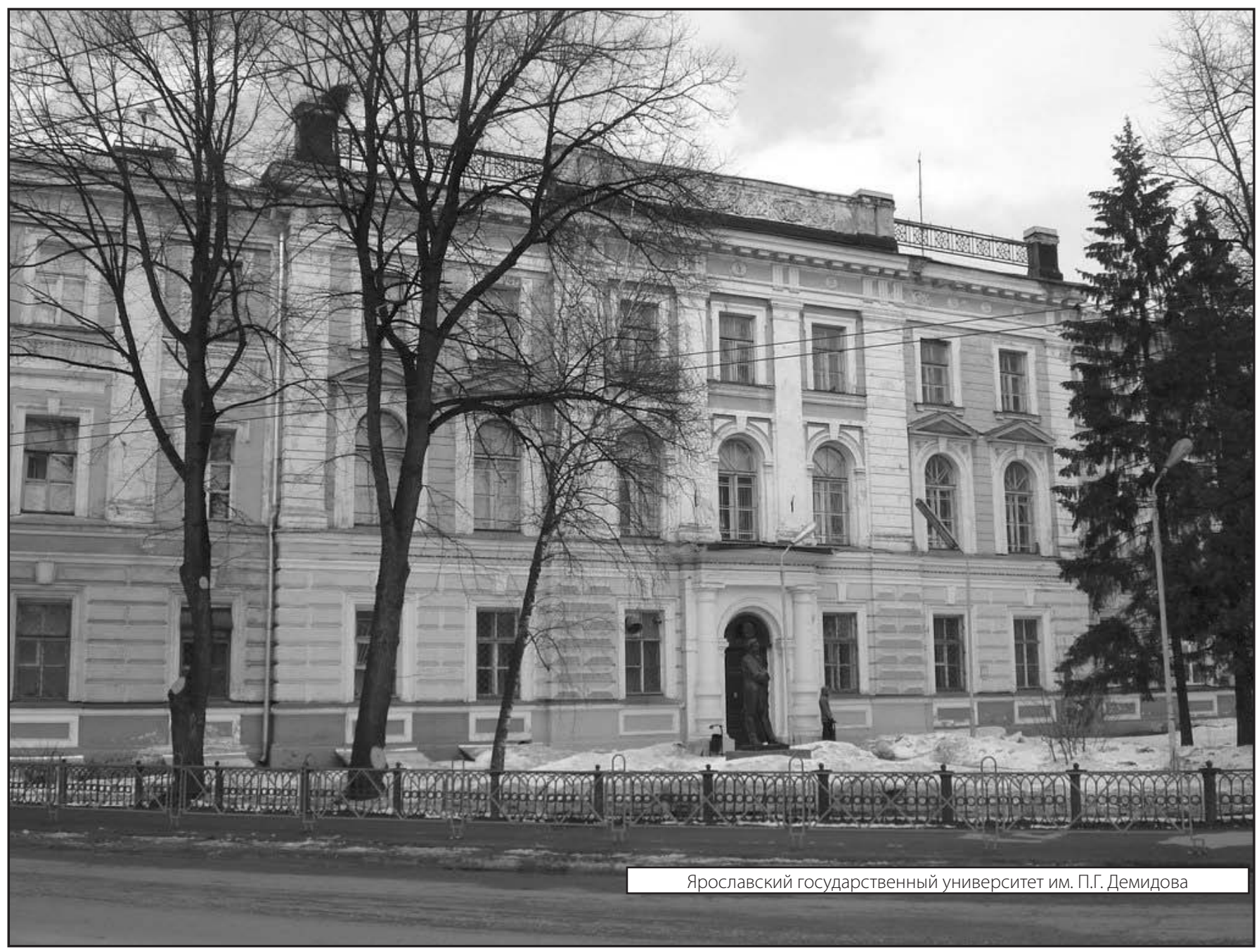

